\title{
Taxonomic Significance of Foliar Epidermis of some Phyllanthus species in South Eastern Nigeria
}

\author{
${ }^{1}$ Uka, C. J., ${ }^{2}$ Okeke, C. U, ${ }^{3}$ Awomukwu, D. A., ${ }^{4}$ Aziagba, B. and ${ }^{5}$ Muoka, R. \\ 1,2,4 Department of Botany, Nnamdi Azikiwe Univerisity, Awka, Anambra State \\ ${ }^{3}$ Department of Biology/ Microbiology, Abia State Polytechnic, P.M.B 7166, Aba, Abia State \\ ${ }^{5}$ Department of Botany, Federal Poltechnic, Oko, Anambra State
}

\begin{abstract}
Leaf epidermal studies were carried out on six species of Phyllanthus L., Family Euphorbiaceae occurring in South Eastern Nigeria. The species investigated include P. amarus Schum and Thonn, P. urinaria Linn., P. odontadenius Mull-Arg., P. niruroides Mull-Arg., P. mullerianus (O. Ktze) Excel and P. discoideus (Baill) Mull-Arg. The study was done in order to investigate their taxonomic relationship and to identify epidermal features that can be recognized and employed as useful taxonomic characters. Qualitative features of the epidermal morphology showed variations in shapes of the epidermal cells and types of stomata, which varied from wavy, polygonal to sinuous and anisocystic, tetracytic to paracytic respectively in the different species. Differences were found in the distribution of the stomata as well as the variation in the cell wall contours and thickness. Also, a quantitative trait such as the stomatal index (SI) was described in details in the present study. A key for identification of the species is provided.
\end{abstract}

Keywords: Phyllanthus species, foliar epidermal shape, stomata types, stomatal index, epidermal cell wall contours .

\section{Introduction}

Phyllanthus is a genus of the Euphorbiaceae family (Spurge family) which has over 6,500 species in 300 genera (Lewis and Elvin-Lewis, 1977). The name "Phyllanthus" means "leaf and flower" because the flower, as well as the fruit, seems to become one with the leaf. Other common names include gripe weed, stonebreaker and leaf flower (Cabieses, 1993). Many members of the genus play important role in supporting tropical rainforest, horticultural value for ornamental, traditional medicine, and food resources. Most are herbs, but some are also shrubs or trees. The plants are monoecious or homogamous. The leaves are simple; alternate or opposite, and some are leathery. The flowers are very small and diclinous. They cluster in cup-shaped structures, and the colours are greenish, whitish or whitish-green, often with glands. The fruit is a lobed-capsule extending from the cup and commonly the long stalk pendant (Wessels-Boer et al., 1976; Lewis and ElvinLewis, 1977).

Phyllanthus species are generally well known for the biologically active compounds they possess. The medicinal values of these plants lie in some chemical substances that produce a definite physiological action on the human body. Chemical compounds isolated from plants include tannins, alkaloids, saponins, phenols, terpenoids, flavonoids, glycosides, vitamins, minerals and antibiotics. These are very useful in economic botany, medicinal chemistry and pharmacognosy; some drugs have been obtained from natural sources while some may be prepared by the modification of the natural ones (Edeoga and Eriata, 2001). Phyllanthus species has long history in traditional system of medicine in every tropical country where it grows. In many countries around the world, Phyllanthus species are used in folk remedies (Foo, 1993). Various species of the genus have been reported to be used in the treatments of liver, kidney and bladder problems, diabetes, appendix inflammation, prostrate problem and intestinal parasites (Heyde, 1990).

Morphological characters are features of external forms or appearance. They currently provide the characters used for hypothesizing phylogenetic relationships. These features have been used for a longer time than the anatomical evidence in the beginnings of plant systematic. Morphological characters are easily observed and find practical use in keys and description. Morphological characters include the external features of the plant parts used, including the particulars of their size, shape and colour. Most plants are classified based on external morphological structures, such as flower and fruits. These structures are not always available on plants because they are seasonal in production. Due to this reason, other means of identification and classification need to be involved; one of which is leaf epidermal studies.

From available literatures, the use of leaf epidermal features in systematic botany is now popular just like the use of other markers like DNA sequence and chemical compositions (Edeoga and Ikem, 2001; Mbagwu and Edeoga, 2006). Epidermal characters are attributes of potential taxonomic significance both at genus and species level found on the leaves of plants. The morphology of the stomata and surrounding epidermal cells of the leaf have long been regarded as useful tools (Cutler, 1984; Stace, 1984). Payne (1970), Dilcher (1974) and 
Wilkinson (1979) were among the early workers that observed the tendency of the cells surrounding the general cells of the stomata to form patterns which were constant within taxa and even families and proposed different terminologies for the description of these cells in recent times. Edeoga, (1991); Edeoga and Osawe, 1996; Mbagwu and Edeoga, (2006) constantly reaffirmed the point that epidermal and cuticular traits of plants could serve as vital tools exploitable in the systematics of the present day angiosperms. Also, different shapes of epidermal cells, type and arrangement of stomata, size and shape of trichomes and number of vascular bundles are all vital in systematic botany (Nwachukwu and Mbagwu, 2006). Some characters or features on the epidermis which are useful taxonomically include several differentiated cell types, epidermal cells, subsidiary cells, guard cells and epidermal hairs (i.e trichomes). These features have been used previously to resolve some taxonomic problems or to contribute to ever increasing taxonomic database in some genera and even families of plants (Watson, 1964)

Although series of documented descriptions of the morphological characteristics and ethnobotanical uses of Phyllanthus are found in various literatures (Burkill, 1994; Oliver, 1959; Hutchinson and Dalziel, 1963). However, the authors did not come across any information on the epidermal features of the foliar organ of these South Eastern Nigeria species of Phyllanthus. It is attempt to reduce this gap of information on these important medicinal plants led to our present choice of study. Hence, the need for this investigation will provide the basic epidermal information that will assist to a great extent in clarifying the confusion in the identity of these taxa.

\section{Collection Of Plant Materials}

\section{Materials And Methods}

Mature plants of the six species P. amarus, P. urinaria, P. niruroides, P. odontadenius, P. mullerianus and P. discoideus were collected from different locations of Eastern Nigeria by various investigators as in Table 2. Only healthy, fresh and succulent parts of the plants were collected. The six specimens were identified and authenticated at the Herbaria of the Department of Botany, Nnamdi Azikiwe University, Awka and the Department of Plant Science and Biotechnology, Michael Okpara University of Agriculture, Umudike. Herbarium specimens were also studied at the various institutions as well making reference to the Flora of West Tropical Africa by Hutchinson and Dalziel (1963).

Table 1: Collection sites of the six Phyllanthus species studied

\begin{tabular}{ll}
\hline SPECIES & SITES OF COLLECTION \\
\hline Phyllanthus amarus & Along the school fence, Abia State Polytechnic, Aba. \\
Phyllanthus urinaria & Field around National Root Crop Research Institute, Umudike. \\
Phyllanthus odontadenius & Road side along National Root Crop Research Institute, Umuahia. \\
Phyllanthus niruroides & Science Village, Nnamdi Azikiwe University, Awka. \\
Phyllanthus discoideus & Near the Herbarium Building, Nnamdi Azikiwe University, Awka. \\
Phyllanthus mullerianus & Near the Herbarium Building, Nnamdi Azikiwe University, Awka. \\
\hline
\end{tabular}

\section{Epidermal Studies}

Fresh plant materials of the different specimens were used for the epidermal studies. To study the epidermal structures of the fresh leaves of the sample, first the epidermal imprints of the leaf lamina were prepared. A domestic adhesive (Quick fix) was applied uniformly on both the upper and lower epidermis of the dried leaves. It is then dried at room temperature. The dried transparent film of "Quick fix" was then stripped off carefully from the surface of the leaf and placed on a clean dry glass slide with the imprint surface uppermost. Cover slip was placed over it and lightly tapped to flatten the film. It was then observed under a compound microscope. Photomicrographs were taken using a Leitz Wetzler Ortholux microscope fitted with a Vivatar-V335 camera.

The stomatal index was determined according to Metcalfe and Chalk (1979), using the formula:

Stomatal Index $(\mathrm{S} . \mathrm{I})=\frac{\mathrm{S}}{\mathrm{E}+\mathrm{S}} \times \frac{100}{1}$

Where:

$\mathrm{S}$ - Number of stomata per unit area

E - Number of epidermal cells in the same area.

\section{Results}

The results of the leaf epidermal features of the six species of Phyllanthus investigated were summarized in Table 1 and Figures1-2. The six species investigated showed variation in the shape of epidermal cells, types of stomata and cell thickness. The study of the epidermal leaf features from species in this section revealed differences in micro morphological characters, some of them showing interesting interspecific variations. P. amarus, P.urinaria and P. niruroides have wavy shape of epidermal wall in both the upper and lower epidermis, while P. odontadenius has sinuous shape in the upper and lower epidermis. On the other hand 
$\mathrm{P}$.mullerianus and P. discoideus showed an irregular polygonal in the upper and lower epidermis except for the lower epidermis of P. discodeus that has an irregular circular shape. The types of stomata varied from anisocytic in the upper and lower epidermis of P. amarus, P. odontadenius and P. niruroides to paracytic in P. urinaria and P. discoideus, except for P. mullerianus that showed a tetracytic stomatal type. The stomatal index varied from $(0.0-20.10 \%)$ in the upper epidermis of the six species while it varied from $(20.0-33.3 \%)$ in the lower epidermis respectively. The cell wall thickness also varied considerably in the respective species. Furthermore, the epidermal cell wall contours displayed an observable variation from curved to straight in the respective species.
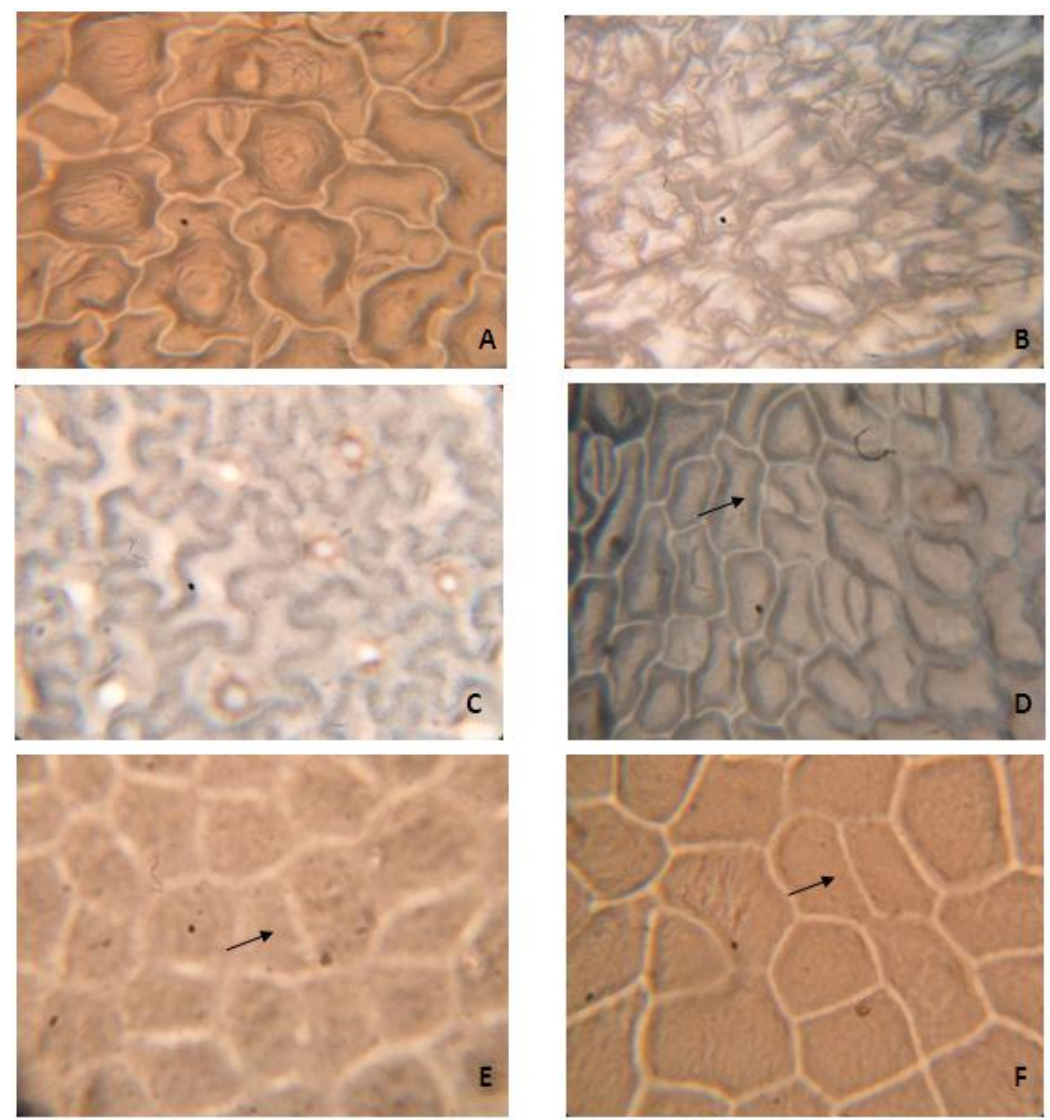

Figure 1. Photomicrographs $(\times 400)$ of Adaxial layer/ upper leaf epidermis of the genus Phyllanthus.

(A) P. amarus, showing anisocytic stomata surrounded by wavy shaped epidermis with thin cell walls.

(B) P. urinaria, showing paracytic stomata surrounded by wavy shaped epidermis with moderately thick cell walls.

(C) P. odontadenius, showing anisocytic stomata surrounded by sinuous shaped epidermis with moderately thick cell walls.

(D) P. niruroides, showing anisocytic stomata surrounded by wavy shaped epidermis with thin cell walls.

(E) P. mullerianus, showing absence of stomata and irregularly polygonal shaped epidermis with thick cell walls.

(F) P. discoideus, showing absence of stomata and irregularly polygonal shaped epidermis with thick cell walls.

(G) $\uparrow$ - Arrow pointing at the wall contours 

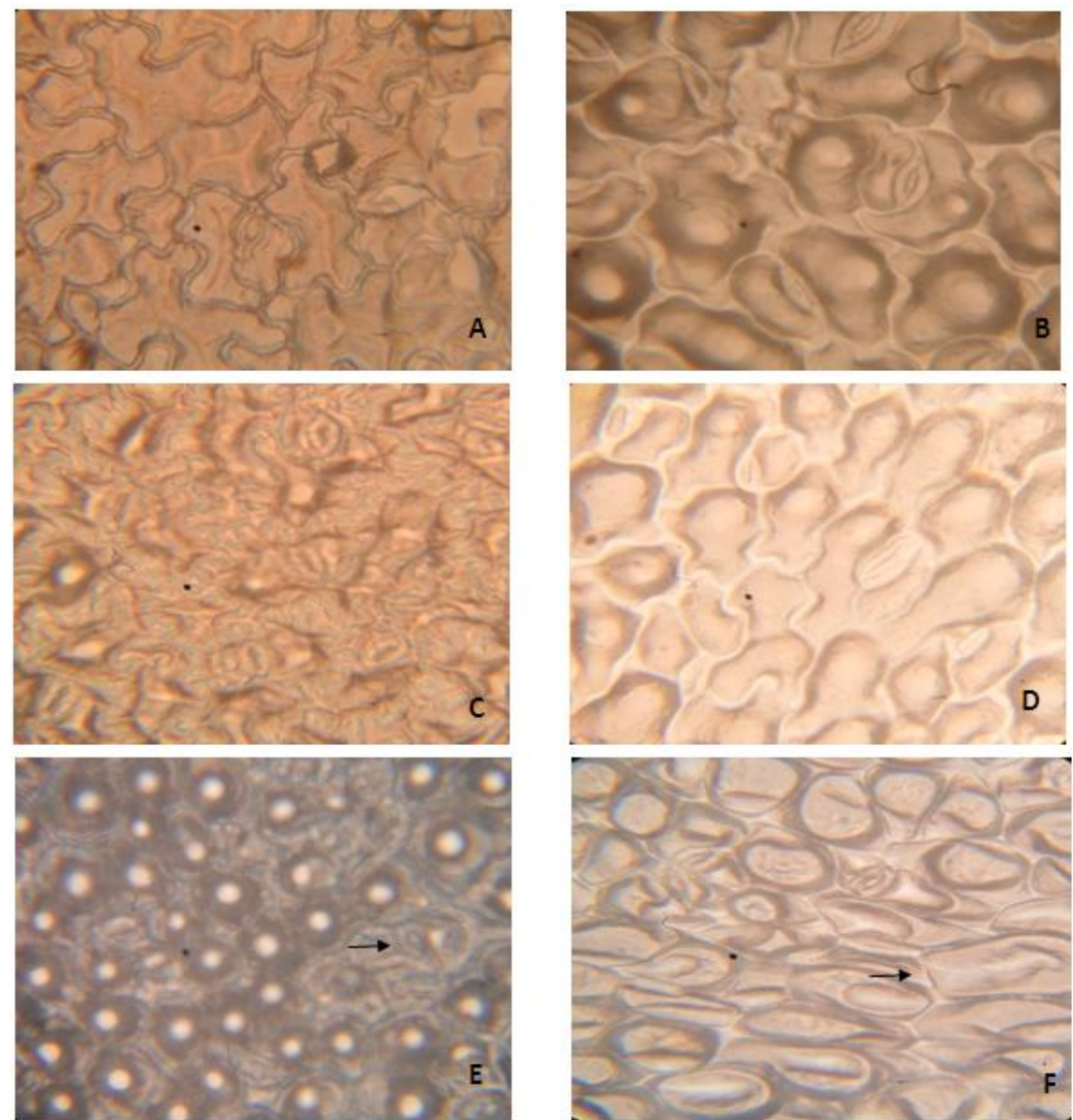

Figure 2. Photomicrographs ( $\times 400)$ of Abaxial layer/ lower leaf epidermis of the genus Phyllanthus.

(A) P. amarus, showing anisocytic stomata surrounded by wavy shaped epidermis with moderately thick cell walls.

(B) P. urinaria, showing paracytic stomata surrounded by wavy shaped epidermis with thin cell walls.

(C) P. odontadenius, showing anisocytic stomata surrounded by sinuous shaped epidermis with moderately thick cell walls.

(D) P. niruroides, showing anisocytic stomata surrounded by wavy shaped epidermis with moderately thick cell walls.

(E) P. mullerianus, showing tetracytic stomata surrounded by irregularly polygonal shaped epidermis with thick cell walls.

(F) P. discoideus, showing paracytic stomata surrounded by irregularly polygonal shaped epidermis with thick cell walls.

(G) $\uparrow$ - Arrow pointing at the wall contours

Table 2: Summary of epidermal characters of the Phyllanthus species

\begin{tabular}{|c|c|c|c|c|c|c|}
\hline Characters & & $\begin{array}{c}\text { Stomatal } \\
\text { Index }(\%)\end{array}$ & $\begin{array}{l}\text { Epidermal } \\
\text { Cell Shape }\end{array}$ & $\begin{array}{c}\text { Stomata } \\
\text { Type }\end{array}$ & $\begin{array}{l}\text { Cell Wall } \\
\text { Thickness }\end{array}$ & $\begin{array}{c}\text { Epidermal } \\
\text { Contours }\end{array}$ \\
\hline \multirow{2}{*}{ P. amarus } & U.E & 20.10 & Wavy & Anisocytic & Thin & Curved \\
\hline & L.E & 26.96 & Wavy & Anisocytic & Moderately thick & Curved \\
\hline \multirow[t]{2}{*}{ P. urinaria } & U.E & 12.10 & Wavy & Paracytic & Moderately thick & Curved \\
\hline & L.E & 33.33 & Wavy & Paracytic & Thin & Curved \\
\hline \multirow{2}{*}{ P. odontadenius } & U.E & 18.53 & Sinuous & Anisocytic & Moderately thick & Curved \\
\hline & L.E & 21.60 & Sinuous & Anisocytic & Moderately thick & Curved \\
\hline \multirow[t]{2}{*}{ P. niruroides } & U.E & 16.67 & Wavy & Anisocytic & Thin & Straight \\
\hline & L.E & 25.96 & Wavy & Anisocytic & Moderately thick & Curved \\
\hline \multirow[t]{2}{*}{ P. mullerianus } & U.E & - & Irregularly & - & Thick & Straight \\
\hline & L.E & 20.00 & $\begin{array}{l}\text { Irregularly } \\
\text { polygonal }\end{array}$ & Tetracytic & Moderately thick & Straight \\
\hline \multirow[t]{2}{*}{ P. discoideus } & U.E & - & $\begin{array}{l}\text { Irregularly } \\
\text { polygonal }\end{array}$ & Paracytic & Thick & Straight \\
\hline & L.E & 23.08 & $\begin{array}{l}\text { Irregularly } \\
\text { circular }\end{array}$ & Paracytic & Moderately thick & Straight \\
\hline
\end{tabular}


KEY:

U.E = Upper epidermis (Adaxial layer).

L.E = Lower epidermis (Abaxial layer)

\section{Discussion}

Phyllanthus species in the Southern Nigeria possessed variable and valuable characters in the leaf epidermis. The different micro-morphological characteristics of the species of Phyllanthus examined can be a reliable tool in the systematic delineation of the taxa. The shape of epidermal cells, types and arrangement of stomata, epidermal cell wall thickness, epidermal cell wall contours and stomatal index are important systematic parameters (Gill and Keratela, 1982; Edeoga, 1991).

The adaxial epidermis of P. mullerianus and P. discoideus were both observed to be absent of stomata. This is a variation that can be used to separate P. mullerianus and P. discodeus from other investigated species. Furthermore, both species seem to possess straight epidermal cell wall contours and thick to moderately thick cell walls on the upper and lower epidermis respectively. But on the contrary, P. mullerianus possessed an irregularly polygonal epidermal shape and tetracytic stomata type on the abaxial epidermis while P. discoideus possessed P. mullerianus an irregularly circular epidermal shape and paracytic stomata type respectively. With this feature, P. mullerianus can be separated from P. discoideus.

The variable characteristics possessed in the stomata type, epidermal cell shape and contours could be valuable in characterizing $\mathrm{P}$. amarus, $\mathrm{P}$. odontadenius, $\mathrm{P}$. niruroides and $\mathrm{P}$. urinaria. The types of stomata using subsidiary cells varied from anisocytic in P. amarus, P. odontadenius and P. niruroides to parasytic in P. urinaria in both the adaxial and abaxial surfaces. With this feature, P. urinaria can be separated from P. amarus, P. odontadenius and P. niruroides. Equally, important is the epidermal cell shape of the respective species studied. P. odontadenius differed from P. amarus and P. urinaria in possessing a conspicuous sinuous epidermal cell shape whereas the later possessed wavy epidermal cell shapes respectively. This epidermal micromorphology is peculiar among the studied species and can be used as a useful taxonomic tool to separate P. odontadenius from the other investigated species. The epidermal cell wall contours possessed variables characters in the Phyllanthus species studied that could be used in their classification. The possession of curved epidermal cell contours in the abaxial and adaxial epidermis of P. amarus, P. urinaria and P. odontadenius could be used to separate P. mullerianus and P. discoideus. This feature is peculiar in P. niruroides in which the adaxial surface possessed straight contours while abaxial surface possessed curved contours. With this attribute, P. niruroides can be delineated from P. amarus.

Furthermore, stomatal index varied in both the upper and lower surfaces of the leaves, and could be used in delineating the species as seen in Table 2 . In these taxa, they are $20.10 \%-26.92 \%$ in P. amarus, $12.10 \%$ $-33.33 \%$ in P. urinaria, $18.53 \%-21.60 \%$ in P. odontadenius, $16.67 \%-25.96 \%$ in P. niruroides, Nil $-20.00 \%$ in P. mullerianus and Nil $-23.08 \%$ in P. discoideus.

The distribution of the stomata showed marked variation in both the upper and lower surfaces of the Phyllanthus species. With the lower surface having more stomata than the upper part, while stomata were absent in the upper surface of both P. mullerianus and P. discoideus. This could be due to adaptation to water loss which is in agreement with Metacalf and Chalk (1950). Mbagwu and Edeoga (2006) observed that stomata are present on both surfaces of leaf but are usually more on the lower epidermis in species of Amaranthus and Vigna respectively. In addition, the shapes of the epidermis and stomata types agrees with the work done by Sayyada et al. (2006) who noted that the anticlinal walls of both the epidermis are wavy and stomata are anisocytic type in some Phyllanthus species in which P. amarus was among them. The shape of epidermal cells, types and arrangement of stomata and size are important systematic parameters. (Gill and Keratela, 1982; Edeoga, 1991). The description on the structure and development conforms to Metcalfe and Chalk (1950) who worked on the epidermal morphology and stomatal types in dicotyledons. This work will therefore help in identifying the various species, using their epidermal characteristics. The epidermal characteristics shared by the six species explains why they are in the same genus, while their differences equally showed they could exist as different species which is of great taxonomic significance.

\section{Dichotomous Bracked Key To Identification Of Species}

1. Stomata; absent in upper epidermis but present in lower epidermis-------------------------------------2

$1^{\mathrm{I}}$. Stomata; present in both upper and lower epidermis-

2. Lower epidermal shape; irregularly polygonal------------------------------------P. mullerianus.

$2^{\mathrm{I}}$.Lower epidermal shape; irregularly circular-------------------------------------------P. discoideus.

3. Stomata type; anisocytic----------------------------------------------------------.4

$3^{\mathrm{I}}$.Stomata type; paracytic -P. urinaria.

4. Adaxial and abaxial epidermal shape; wavy-

$4^{\mathrm{I}}$.Adaxial and abaxial epidermal shape; sinuous P. odontadenius. 
5. Upper epidermal cell wall contours; straight P. niruroides. $5^{\mathrm{I}}$.Upper epidermal cell wall contours; curved -P. amarus.

\section{References}

[1]. Burkill, H. M. (1994). The Useful Plants of West Tropical Africa. vol.2. Families E-I. Royal Botanic Garden, Kew. p. 605.

[2]. Cabieses, F. (1993). Apuntes de medicina trational. La Racionalizcion de lo Irracional. "Notes on Traditional Medicine". Consejo Nacional de Ciencia Y Technologia CONCYTEC Lima-Peru. p. 414

[3]. Cutler, D. F. (1984). Anatomy and Embryology. In: Heywood, V. H. \& Moore, D. M. (Eds), Current Concepts in Plant Taxonomy. pp. 107-133.

[4]. Dilcher, D. L. (1974). Approaches to the identification angiosperm leaf remains. Bot Rev., 40: 1-157.

[5]. Edeoga, H. O. (1991). Comparative morphology of the leaf epidermis of Costus afer - C. lucansianus (Costaceae) complex and its system importance. Nat. Sci., 24: 1-243.

[6]. Edeoga, H. O. and Ikem, C. I. (2001). Comparative morphology of leaf epidermis in three species of Boerhevia L. J. Econ Tax. Bot. 19: $197-205$

[7]. Edeoga, H. O and Osawe, I. O. (1996). Cuticular studies of some Nigerian species of Senna. Tourn. Ex Mill. (Syn Casia Tourn. Ex. L): Leguminosae Caesalpinoideae. Acta Phytotax Geobot., 47: 41-46.

[8]. Edeoga, H. O. and Eriata, D. O. (2001). Alkaloid, tannin and saponin contents of some medicinal plants. Journal of Medicinal Aromatic Plant Sciences, 3: 344-349.

[9]. Foo, L. Y. (1993). Amarulone, A novel cyclic hydrolysable tannin from Phyllanthus amarus. Natural Products Letters, 3: 45-52.

[10]. Gill, L. S. and Karatela, Y. Y. (1985). Epidermal morphology and stomatal ontogeny in some West African Convolulaceae species. Herba Hungarice, 24: 11-17.

[11]. Heyde, H. (1990). Medicjin planten in Suriname. (Den dresi wiwiri foe Sranan). "Medicinal Plants in Suriname". Uity Stichting Gizondheidsplante Informaite (SGI) Paramaribo. p. 157.

[12]. Hutchinson, J. and Dalziel, M. D. (1963) Flora of West Tropical Africa, vol. 2. Crown Agents, London, UK.

[13]. Lewis W. H., Elvin-Lewis, M. P. H. (1977). Medicinal Botany Plants Affecting Man's Health. John Wiley \& Sons, New York. p.515.

[14]. Mbagwu, F. N. and Edeoga, H. O. (2006). Observations on the vegetative and floral morphology of some Vigna species (Leguminosae-Papilionoideae). Pakistan Journal of Biological Sciences 9(9): 1754-1758.

[15]. Metcalfe, C. R. and Chalk, L. (1979). Anatomy of the Dicotyledons, Systematic Anatomy of the Leaf and Stem. vol. I. 2nd edn. Clarendon Press, Oxford, London. pp.65-90

[16]. Nwachukwu, C. U. and Mbagwu, F. N. (2006). Morphological features in some species of Indigofera L. (LeguminosaePapilionoideae). Journal of Fish. Int., 1: 50-54.

[17]. Oliver, B. (1959). Nigeria`s Useful Plants II (1) Nigerian Fields 24: 13-34

[18]. Payne, W. W. (1970). Heliocytic and allelocytic stomata; unrecognized patterns in the dicotyledonae. American Journal of Botany., 57: 140-147.

[19]. Sayyada, K., Vartika, R., Ajay, K. S. R., Shanta, M. (2006). Comparative pharmacognistic studies of three Phyllanthus species. Journal of Ethnopharmacology. 104: 79-86.

[20]. Stace, C. A. (1984). The Taxonomic Importance of the Leaf Surface. In: Heywood, V. H. and Moore, D. M. (eds) Current Concepts in Plant Taxonomy, London. pp. 67-105.

[21]. Watson, L. (1964). The taxonomic significance of certain anatomical observation on Ericaceae. New Phytologist. 63: 274-280

[22]. Wessels-Boer, J. G., Hekking, W. H. A and Schulz, J. P. (1976). "Why do say that I am not beautiful. Introduction to the flora and vegetation of Suriname; Part I and II" Natuurgids serie B. No.4 Stinasu Paramaribo.

[23]. Wilkinson, H. P. (1979). The plant surface (mainly leaf) In: Metcalfe, C. R. and Chalk, L., (eds.) Anatomy of the dicotyledons, vol. 1, 2nd edn. pp. 97-165 